\title{
PENGETAHUAN HIV/AIDS PADA REMAJA MELALUI METODE BIBLIOTHERAPI DITINJAU DARI JENIS KELAMIN DI PUSKESMAS PUGER JEMBER
}

\section{Adolescent's Knowledge of HIV/AIDS through Bibliotherapy Method Based on Gender in Puger Jember Public Health Center}

\author{
Iis Rahmawati ${ }^{1 *}$, Dini Kurniawati ${ }^{1}$, Murtaqib ${ }^{2}$ \\ ${ }^{1}$ Departemen Keperawatan Maternitas dan Anak, Fakultas Keperawatan, Universitas Jember \\ ${ }^{2}$ Departemen Keperawatan Medikal Bedah, Fakultas Keperawatan, Universitas Jember \\ "E-mail: rahmawati.psik@gmail.com
}

Naskah masuk 16 Maret 2020; review 9 Juni 2020; disetujui terbit 26 Juni 2020

\begin{abstract}
Background: HIV/AIDS cases are developing very rapidly throughout the world. The increase in cases of HIVIAIDS among adolescents is still related to the lack of knowledge of adolescents on HIV/AIDS.

Objective: This study aimed to describe the knowledge of adolescents on HIV/AIDS through bibliotherapy methods based on sex to contribute to program planners and decision makers in selecting methods in informing HIV/AIDS knowledge.

Method: The study design was quasi experimental. The study location is in the working area of Puger Public Health Center. The study was conducted in July-September 2019. The sample in this study was 44 adolescents consisting of 22 respondents of male adolescents' group and 22 respondents of female adolescents' group using purposive sampling technique with inclusion criteria namely adolescents living in the work area of Puger Public Health Center, aged 16-17 years, adolescent boys and girls who are willing to be respondents, having no obstacle in reading and in good health. The study instrument used was questionnaire of knowledge. Data analysis used Wilcoxon and Mann Whitney test with p-value <0.05.

Results: The results of analysis showed significant differences before and after the therapy in the group of adolescent girls $(p$-value $=0.002)$ and adolescent boys ( $p$-value $=0.043)$. Adolescent boys and girls both have an influence although the influence occurred was not as significant as those occurred in the group of adolescent girls.

Conclusion: The method of bibliotherapy had an influence on increasing knowledge in both groups of adolescent girls and boys, yet more emphasis was found on adolescent girls, thus the bibliotherapy method is more effective if given to the groups of adolescent girls. Therefore, it is recommended to find a more appropriate method for groups of adolescent boys.
\end{abstract}

Keywords: bibliotherapy, HIV/AIDS, adolescent girls, adolescent boys

\begin{abstract}
Abstrak
Latar Belakang: Kasus HIV/AIDS berkembang sangat cepat di seluruh dunia. Peningkatan kasus HIV/AIDS di kalangan remaja berkaitan dengan masih rendahnya pengetahuan remaja tentang HIV/AIDS.

Tujuan: Penelitian ini bertujuan untuk memaparkan pengetahuan remaja tentang HIV/AIDS melalui metode biblioterapi ditinjau jenis kelamin untuk memberikan kontribusi pemikiran bagi para perencana program dan pengambil keputusan dalam memilih metode penyampaian mengenai pengetahuan HIV/AIDS.

Metode: Jenis penelitian ini adalah penelitian quasi experiment. Lokasi penelitian di wilayah kerja Puskesmas Puger. Penelitian dilakukan pada Bulan Juli-September 2019. Sampel dalam penelitian ini adalah 44 orang remaja yang terdiri dari 22 responden kelompok remaja laki-laki dan 22 responden kelompok remaja perempuan, dengan teknik penentuan sampel menggunakan purposive sampling dengan kriteria inklusi yaitu remaja tinggal di wilayah kerja Puskesmas Puger, berusia 16-17 tahun, remaja laki-laki dan perempuan yang bersedia menjadi responden, tidak memiliki hambatan dalam membaca serta dalam keadaan sehat. Instrumen penelitian yang digunakan adalah lembar kuesioner pengetahuan. Analisa data menggunakan uji Wilcocon dan Mann Whitney dengan $p$ value $<0,05$. Hasil: Hasil analisis menunjukan perbedaan yang signifikan sebelum dan sesudah terapi pada kelompok remaja perempuan ( $p$-value $=0,002)$ dan kelompok remaja laki-laki ( $p$-value $=0,043)$. Remaja laki-laki dan perempuan sama-sama memiliki pengaruh tetapi pengaruh yang terjadi tidaklah sesignifikan pada kelompok remaja perempuan.

Kesimpulan: Metode biblioterapi memiliki pengaruh terhadap peningkatan pengetahuan baik pada kelompok remaja perempuan maupun remaja laki-laki, tetapi yang lebih memiliki pengaruh yaitu terhadap remaja perempuan, maka metode biblioterapi ini lebih efektif jika diberikan kepada kelompok remaja perempuan. Untuk itu disarankan agar mencari metode yang lebih tepat untuk kelompok remaja laki-laki.
\end{abstract}

Kata kunci: biblioterapi, HIV/AIDS, remaja perempuan, remaja laki-laki 


\section{PENDAHULUAN}

Kasus HIV/AIDS berkembang sangat cepat di seluruh dunia. Penderita HIV (Human Immunodeficiency Virus) di seluruh dunia sampai dengan 2017 mencapai 36,9 juta orang dengan penderita Infeksi baru HIV mencapai 1,8 juta orang. ${ }^{1,2}$ Jumlah kasus HIV di Indonesia, sejak 2005 sampai dengan Maret 2019 mencapai 338.363 orang, sedangkan jumlah kasus AIDS (Acquired Immunodeficiency Syndrome) yang dilaporkan sejak pertama kali ditemukan pada 1987 sampai dengan Maret 2019 mencapai 115.601 orang. Transmisi HIV dari Januari sampai dengan Maret 2019 sebanyak 11.081 orang, sedangkan kasus AIDS mencapai 1.536 orang. ${ }^{3}$ Situasi penyebaran HIV/AIDS di Indonesia menunjukkan jumlah kumulatif kasus HIV/AIDS yaitu 466.859 yang terdiri atas 349.882 HIV dan 116.977 AIDS. ${ }^{3}$

Penderita HIV/AIDS bukan hanya menyerang pada orang dewasa tetapi juga pada anak-anak serta remaja. Sebanyak 17,8 juta kasus HIV di antaranya merupakan wanita berusia lebih dari 15 tahun dan 1,8 juta kasus merupakan anak berusia kurang dari 15 tahun, serta mengalami peningkatan kasus baru sebesar 1,9 juta pada usia lebih dari 15 tahun dan 150.000 anak usia kurang dari 15 tahun pada tahun $2015 .{ }^{4}$ Angka kejadian remaja yang terinfeksi HIV di Indonesia berjumlah 28.060 remaja $(15,2$ persen) dan sebanyak 2.089 remaja (3 persen) di antaranya sudah dengan AIDS. ${ }^{5}$

Penderita HIV di Jawa Timur menduduki peringkat kedua di Indonesia. ${ }^{6}$ Kasus HIV di Kabupaten Jember mencapai 4.204 kasus perDesember 2018. Jumlah penderita yang tertinggi berada di Kecamatan Puger, Kencong, Gumukmas, Wuluhan, Kaliwates, Sumbersari, Umbulsari, Bangsalsari, Ambulu, dan Patrang. ${ }^{7}$ Prevelensi kasus HIV/AIDS tertinggi yaitu di Kecamatan Puger tercatat sebanyak 357 kasus. ${ }^{8}$ Mengacu pada kondisi Kecamatan Puger yang merupakan wilayah dengan angka kejadian kasus HIV/AIDS tertinggi di Kabupaten Jember, maka tidak menutup kemungkinan sebagian besar remajanya telah terpapar mengenai HIV/AIDS baik benar maupun salah. Risiko penularan dan pengaruh pengetahuan pada remaja di wilayah ini lebih besar karena terdapat bekas lokalisasi atau prostitusi pada salah satu desa di Kecamatan Puger. ${ }^{9}$

Pengetahuan remaja mengenai HIV/AIDS menjadi aspek yang sangat penting dalam perubahan sikap maupun perilaku. Hal tersebut merupakan bagian dari Sustainable Development Goals (SDGs) dalam indikator ke-3 dan harus dipantau secara berkala oleh semua masyarakat yang tinggal di Indonesia. Terbatasnya atau tidak tersedianya informasi mengenai HIV/AIDS pada remaja dapat menimbulkan dampak dan perilaku yang negatif dan dapat meningkatkan kasus baru penderita HIV. ${ }^{4}$

Remaja merupakan generasi penerus bangsa, sehingga diperlukan adanya bimbingan dan arahan yang benar mengenai pengetahuan HIV/AIDS agar dapat menjadi remaja yang sehat dan berkualitas. Hal tersebut sesuai dengan Peraturan Menteri Kesehatan Nomor 21 tahun 2013 tentang Penanggulangan HIV dan AIDS yang tertulis bahwa salah satu bentuk kegiatan dalam penanggulangan HIV/AIDS adalah upaya promotif yang bertujuan untuk meningkatkan pengetahuan yang benar dan komprehensif mengenai pencegahan penularan HIV. ${ }^{10}$ Undang-Undang Nomor 36 Tahun 2009 Pasal 73 juga menjelaskan bahwa Pemerintah wajib menjamin ketersediaan sarana informasi dan sarana pelayanan kesehatan reproduksi yang aman, bermutu, dan terjangkau masyarakat, termasuk keluarga berencana. ${ }^{11}$ Oleh karena itu, salah satu tujuan penelitian ini adalah untuk mencapai hal tersebut.

Kurangnya pengetahuan remaja mengenai HIV/AIDS dapat diatasi dengan menambah informasi tentang HIV/AIDS dengan pendidikan di lingkungan sekolah, bertukar cerita bersama teman, bercerita kepada orang tua, serta melalui bahan bacaan untuk membantu remaja untuk menambah informasi. Penggunaan buku dalam proses terapeutik dan supportif disebut biblioterapi. ${ }^{12}$

"Korespondensi: rahmawati.psik@gmail.com

(C) Badan Penelitian dan Pengembangan Kesehatan ISSN: 2354-8762 (elektronik); ISSN: 2087-703X (cetak) 
Biblioterapi merupakan aktivitas menggunakan media bahan bacaan dengan tujuan untuk mengurangi bahkan menyelesaikan permasalahan yang sedang dialami oleh individu. $^{13}$ Metode ini digunakan untuk membentuk konsep diri positif pada remaja, memotivasi remaja, serta melihat berbagai pilihan dalam menyelesaikan masalah. Biblioterapi memiliki cerita yang dapat memberikan dampak efektif karena isi cerita lebih spesifik, sesuai dengan tingkat karakteristik subyek, memiliki nilai belajar yang tinggi sehingga menjadi salah satu intervensi yang memiliki kekuatan untuk mengubah. ${ }^{14}$

Penelitian yang dilakukan oleh Hidayah dkk (2016) mengenai pengaruh metode biblioterapi terhadap pengetahuan remaja tentang hygiene menstruasi di SMP Negeri 2 Mayang Kabupaten Jember mendapatkan hasil bahwa terdapat pengaruh metode biblioterapi terhadap pengetahuan remaja tentang hygiene menstruasi di SMP Negeri 2 Mayang. Hasil serupa juga terdapat pada penelitian Rohmah (2015) yang berjudul pengaruh metode biblioterapi terhadap kemampuan mencuci tangan pakai sabun pada siswa kelas 2 di SDN Banjarsengon 1 Kecamatan Patrang Kabupaten Jember. Hasil penelitian menunjukan pemberian metode biblioterapi berpengaruh signifikan terhadap kemampuan siswa kelas di 2 SDN Banjarsengon 1 Kecamatan Patrang Kabupaten Jember dalam melakukan cuci tangan pakai sabun.

Berdasarkan hasil penelitian sebelumnya bahwa metode bibliotherapi berpengaruh terhadap pengetahuan tetapi belum diteliti untuk pengetahuan mengenai HIV/AIDS serta dari hasil penelitian sebelumnya didapatkan bahwa kasus penderita HIV/AIDS terbanyak berjenis kelamin perempuan, maka perlu memperhatikan faktor jenis kelamin dalam menangani permasalahan HIV/AIDS melalui upaya pencegahan, agar angka kejadian HIV/AIDS tidak bertambah banyak tiap tahunnya, sehingga peneliti tertarik untuk melakukan penelitian mengenai pengaruh metode biblioterapi terhadap pengetahuan remaja tentang HIV/AIDS ditinjau dari jenis kelamin di Wilayah Kerja Puskesmas Puger Kabupaten Jember.

\section{METODE}

Desain penelitian dalam penelitian ini adalah quasi experiment design. Rancangan ini berupaya untuk mengetahui pengaruh antara variabel pada situasi atau sekelompok subyek tertentu. Sampel pada penelitian ini adalah 44 responden usia remaja yang terdiri dari 22 responden kelompok remaja laki-laki dan 22 responden kelompok remaja perempuan yang memenuhi kriteria inklusi dengan teknik pengambilan sampel menggunakan teknik nonprobability sampling dengan menggunakan purposive sampling dengan kriteria inklusi yaitu remaja yang tinggal di wilayah kerja Puskesmas Puger, berusia 16 - 17 tahun, remaja laki-laki dan perempuan yang bersedia menjadi responden, tidak memiliki hambatan dalam membaca, serta dalam keadaan sehat.

Instrumen penelitian yang digunakan adalah lembar kuesioner pengetahuan. Kuesioner berisi 30 pertanyaan pengetahuan remaja tentang HIV/AIDS yang mana merupakan pertanyaan tertutup. Kuesioner ini dimodifikasi dari kuesioner dalam penelitian sebelumnya yang dilakukan oleh Andriansyah dan Rifai (2016) berisi 24 pertanyaan yang kemudian dimodifikasi oleh peneliti menjadi 30 jenis pertanyaan. Kuesioner pengetahuan remaja mengenai HIV/AIDS dengan model benar dan salah. Pertanyaan favourable mendapatkan nilai 1 jika jawaban benar dan nilai 0 untuk jawaban salah. Sedangkan, untuk pertanyaan unfavourable mendapatkan nilai 0 jika jawaban benar dan nilai 1 jika jawaban salah. Kuesioner pengetahuan remaja tentang HIV/AIDS ini memiliki rentang nilai $0-30$.

Peneliti kemudian melakukan pre-test pada kedua kelompok dengan membagikan kuesioner tingkat pengetahuan tentang HIV/AIDS kepada responden guna mengetahui tingkat pengetahuan. Peneliti selanjutnya melakukan metode biblioterapi kepada kedua kelompok tersebut dan dilanjutkan dengan diskusi. Peneliti melakukan post-test pada tahap terakhir untuk melakukan evaluasi. Analisa univariat digunakan untuk mengetahui karakteristik responden, sedangkan untuk mengetahui tingkat pengetahuan remaja tentang HIV/AIDS dilakukan dengan analisa bivariat menggunakan uji Wilcoxon dan Mann Whitney dengan p-value $<0,05$. 
Penelitian ini sudah mendapatkan layak etik dari Fakultas Kedokteran Gigi Universitas Jember dengan Nomor 872/UN25.8/KEPK/ DL/2020.

\section{HASIL}

Hasil penelitian karakteristik responden berdasarkan jenis kelamin di wilayah kerja Puskesmas Puger Kabupaten Jember ditunjukkan pada Tabel 1 berikut.

Tabel 1. Distribusi Frekuensi Karakteristik Responden Berdasarkan Jenis Kelamin di Wilayah Kerja Puskesmas Puger Kabupaten Jember Tahun $2020(n=44)$

\begin{tabular}{ccc}
\hline Karakteristik & $\begin{array}{c}\text { Frekuensi } \\
\text { (orang) }\end{array}$ & $\begin{array}{c}\text { Persentase } \\
(\boldsymbol{\%})\end{array}$ \\
\hline Jenis Kelamin & & \\
Laki-laki & 22 & 50,0 \\
Perempuan & 22 & 50,0 \\
\hline Total & $\mathbf{4 4}$ & $\mathbf{1 0 0}$ \\
\hline
\end{tabular}

Tabel 1 menunjukkan distribusi karakteristik responden yaitu jumlah responden 50 persen baik pada remaja laki-laki maupun perempuan terpenuhi.

Hasil penelitian pre-test dan post-test pengetahuan pada kelompok remaja laki-laki maupun perempuan tentang HIV/AIDS di Wilayah Kerja Puskesmas Puger Kabupaten Jember ditunjukkan pada Tabel 2.

Tabel 2 menunjukkan nilai pre-test dan posttest pengetahuan pada kelompok remaja perempuan memiliki rata-rata lebih tinggi dari pada kelompok remaja laki-laki dengan ratarata pre-test 20,10 dan rata-rata post-test 27,00. Responden kelompok remaja perempuan memiliki nilai pre-test mimimum 20 dan maksimum 30 serta nilai post-test minimum 33 dan maksimum 40, sedangkan responden kelompok remaja laki-laki memiliki nilai pretest mimimum 16 dan maksimum 26 serta nilai post-test minimum 17 dan maksimum 28.

Tabel 2. Gambaran Hasil Pre-test dan Post-test Pengetahuan tentang HIV/AIDS pada Kelompok Remaja Laki-Laki dan Kelompok Remaja Perempuan di Wilayah Kerja Puskesmas Puger Kabupaten Jember Tahun $2020(n=44)$

\begin{tabular}{lcccc}
\hline \multirow{2}{*}{ Kelompok } & \multicolumn{2}{c}{ Perempuan } & \multicolumn{2}{c}{ Laki-laki } \\
\cline { 2 - 5 } & Pre-test & Post-test & Pre-test & Post-test \\
\hline Mean & 20,10 & 27,00 & 20,10 & 21,25 \\
SD & 2,835 & 1,615 & 2,870 & 3,115 \\
Min & 20 & 30 & 16 & 17 \\
Maks & 33 & 40 & 26 & 28 \\
\hline
\end{tabular}

Tabel 3. Perbedaan Antara Nilai Pre-test dan Post-test Pengetahuan Kelompok Remaja LakiLaki dan Kelompok Perempuan tentang HIV/AIDS di Wilayah kerja Puskesmas Puger Kabupaten Jember Tahun 2020 (n=44)

\begin{tabular}{llcc}
\hline \multicolumn{2}{c}{ Kelompok } & Mean & Difference \\
\hline Remaja perempuan & Pre-test & 20,10 & 6,833 \\
& Post-test & 27,00 & \\
\hline Remaja laki-laki & Pre-test & 20,10 & 1,146 \\
& Post-test & 21,25 & \\
\hline
\end{tabular}


Hasil penelitian perbedaan pre-test dan posttest pengetahuan pada kelompok remaja lakilaki maupun perempuan tentang HIV/AIDS di Wilayah Kerja Puskesmas Puger Kabupaten Jember ditunjukkan pada Tabel 3 berikut.

Tabel 3 menunjukkan bahwa terdapat perbedaan rata-rata pengetahuan kelompok remaja perempuan yaitu 6,833. Peningkatan nilai terjadi pada seluruh responden pada kelompok remaja perempuan. Berdasarkan Tabel 3 diketahui pula bahwa terdapat perbedaan rata-rata pengetahuan remaja lakilaki yaitu 1,146 .

Hasil uji Wilcoxon pengetahuan pada kelompok remaja laki-laki maupun perempuan tentang HIV/AIDS di Wilayah Kerja Puskesmas Puger Kabupaten Jember ditunjukkan pada Tabel 4 berikut.

\section{Tabel 4. Hasil Uji Wilcoxon Pengetahuan Remaja Laki-Laki dan Perempuan Tentang HIV/AIDS di Wilayah Kerja Puskesmas Puger Kabupaten Jember berdasarkan Pre-test dan Post-test Tahun $2020(\mathrm{n}=44)$}

\begin{tabular}{ccc}
\hline \multirow{2}{*}{ Kelompok } & Perempuan & Laki-laki \\
\cline { 2 - 3 } & Pre-test dan Post-test & Pre-test dan Post-test \\
\hline Z & -3.162 & $-2,333$ \\
p-value & 0,002 & 0,043 \\
\hline
\end{tabular}

Tabel 4 menunjukkan bahwa hasil uji wilcoxon pada kelompok remaja perempuan memiliki nilai $\mathrm{p}<0,05$ yaitu 0,002 yang berarti bahwa adanya perbedaan yang signifikan antara nilai pre-test dan post-test. Berbeda dengan hasil uji wilcoxon pada kelompok remaja perempuan yang memiliki $\mathrm{p}<0,05$ yaitu 0,043 walaupun terdapat perbedaan namun hal tersebut menunjukan perbedaan yang terjadi tidaklah sesignifikan antara pre-test dan post-test pada kelompok remaja perempuan.

Hasil Uji Mann Whitney pengetahuan pada kelompok remaja laki-laki maupun perempuan tentang HIV/AIDS di Wilayah Kerja Puskesmas Puger Kabupaten Jember

$$
\begin{aligned}
& \text { Tabel 5. Hasil Uji Mann Whitney } \\
& \text { Pengetahuan Remaja laki-laki dan } \\
& \text { perempuan tentang HIV/AIDS di } \\
& \text { Wilayah kerja Puskesmas Puger } \\
& \text { Kabupaten Jember, tahun } 2020(n=44)
\end{aligned}
$$

\begin{tabular}{lcc}
\hline Kelompok & $\mathbf{Z}$ & $\boldsymbol{p}$-value \\
& & \\
\hline Laki-laki & $-3,057$ & 0,001 \\
Perempuan & & \\
\hline
\end{tabular}

Tabel 5 menunjukkan bahwa hasil uji Mann Whitney antara kelompok remaja perempuan dan kelompok remaja laki-laki memiliki nilai $p<0,001$. Hal ini menunjukan bahwa terdapat perbedaan yang signifikan antara kelompok remaja perempuan dan kelompok remaja lakilaki.

\section{PEMBAHASAN}

Biblioterapi merupakan sebuah metode terapi yang menggunakan literatur atau buku untuk menciptakan interaksi yang bersifat terapeutik, dapat merubah proses kognitif, emosional dan juga perilaku dari seseorang sehingga orang tersebut mendapatkan pemahaman yang tepat dan benar dalam penyelesaian masalah yang dihadapi. ${ }^{17}$ Metode ini dilakukan dengan memberikan buku atau literatur kepada seseorang di mana buku atau literatur tersebut memiliki relevansi atau kesesuaian dengan masalah yang seseorang hadapi. Proses belajar menggunakan metode biblioterapi diharapkan dapat menambah wawasan dan mengatasi atau memberi solusi terhadap masalah yang seseorang hadapi serta mampu merubah perilaku sesuai dengan apa yang telah dipelajari.

Pelaksanaan dalam penelitian ini ada empat tahap biblioterapi, yaitu: 1) Recognition yaitu responden diberikan materi yang memiliki relevansi atau kesesuaian dengan permasalahan 
yang dialami. Respon yang pembaca berikan juga berbeda-beda, ada yang terjadi secara langsung dan ada juga yang membutuhkan waktu. 2) Examination merupakan tahap responden tidak hanya membaca juga melakukan eksplorasi terhadap pikiran dan perasaan yang dimiliki. 3) Juxtaposition (perbandingan) responden mulai menempatkan diri mereka berada dalam situasi yang dihadapi tokoh dalam bacaan atau mungkin seseorang akan mulai membandingkan dirinya dengan tokoh atau peristiwa dalam bacaan. 4) Application to self, responden mulai menyadari tentang dirinya sendiri dan mulai melihat bagaimana sikap dan perilaku dalam sudut pandang yang baru. Setelah semua tahapan terlalui dengan baik maka responden harus memiliki kesadaran dalam berpikir dan membuat komitmen dengan dirinya sendiri untuk merubah sikap dan perilaku yang baru sesuai dengan apa yang sudah dipelajari. ${ }^{17}$

Hasil penelitian menunjukkan bahwa metode biblioterapi pada remaja perempuan ini lebih berpengaruh signifikan dibandingkan dengan remaja laki-laki. Laki-laki dan perempuan tidak hanya berbeda dalam bentuk fisik dan fungsi reproduksi, tetapi juga pada banyak karakteristik lain, termasuk proses pembelajaran, perkembangan bahasa, dan cara mereka memecahkan masalah intelektual. Perbedaan jenis kelamin telah diamati dalam fungsi kognitif dan struktur otak. Berdasarkan hasil penelitian menunjukkan bahwa remaja laki-laki memiliki otak yang lebih besar daripada remaja perempuan dengan status kesehatan yang sama. Secara fisik, otak remaja laki-laki lebih besar daripada otak remaja perempuan di semua lokasi, meskipun pembesaran remaja laki-laki yang paling menonjol adalah di bagian frontal dan oksipital. Remaja lakilaki memiliki belahan otak kanan lebih tebal. Hal ini yang menyebabkan laki-laki cenderung lebih spasial dan matematika. Sedangkan pada remaja perempuan memiliki belahan otak kiri yang lebih tebal. ${ }^{18}$

Teori Roger Sperry mengatakan bahwa seseorang yang sedang membaca akan menggunakan otak kirinya yang besifat logis, linier, intelektual, analitik dan rasional. Ketika membaca informasi berupa kata, kalimat bahkan gambar akan ditangkap oleh indra penglihatan dan akan disampaikan ke otak oleh optic chiasm. Oleh karena itu, kegiatan membaca akan membuat pembaca mengiterprestasikan jalan pikiran dari penulis, menerjemahkan simbol dan huruf kedalam sebuah kata maupun kalimat yang memiliki makna tertentu. Perasaan yang didapat oleh pembaca dapat merefleksikan diri dan mendorong perilaku lebih positif. ${ }^{19}$ Selain itu, sebuah saluran besar serat saraf yang memungkinkan aliran sinaps antara kedua belahan otak lebih besar pada perempuan, dibandingkan dengan laki-laki. Semakin besar ukuran corpus callosum memungkinkan lebih banyak transmisi antara dua belahan. Jadi perempuan menggunakan kedua belahan otak untuk menciptakan lebih banyak sinaps antara kedua sisi otak. ${ }^{20}$

Hasil penelitian menunjukkan bahwa ada beberapa hal di mana remaja laki-laki cenderung lebih baik dibandingkan dengan remaja perempuan dan sebaliknya. Lobus oksipital remaja laki-laki lebih berkembang yang memungkinkan mereka untuk melihat lebih kompleks. Remaja laki-laki juga memerlukan lebih banyak gerakan ketika belajar. Otak remaja perempuan lebih terdesentralisasi. Otak remaja perempuan memiliki kemampuan lebih besar untuk multitasking karena otak mereka lebih aktif. Perempuan menggunakan berbagai bagian dari otak mereka ketika mereka melakukan tugas tunggal. Otak remaja perempuan lebih terintegrasi dengan koneksi yang lebih kompleks antara kedua belahan otak. Pikiran dan emosi pada otak remaja perempuan lebih kompleks dibandingkan dengan otak remaja laki-laki. Perempuan bisa berpikir logis dan emosional pada saat yang sama. Hasil penelitian menunjukkan bahwa remaja perempuan umumnya dapat mengingat daftar kata atau paragraf teks yang lebih baik daripada pria. $^{21}$

Hasil studi pencitraan otak menunjukkan bahwa pada neuron di kedua sisi otak remaja perempuan yang aktif ketika mereka mendengarkan, sementara di neuron remaja laki-laki hanya pada satu sisi otak yang diaktifkan. Remaja laki-laki dan remaja perempuan sama dalam memproses katakata, tetapi dalam penafsiran seluruh kalimat, remaja perempuan menggunakan kedua sisi otak sedangkan remaja laki-laki hanya menggunakan satu sisi. ${ }^{22}$ Berdasarkan hal 
tersebut, maka remaja perempuan memiliki keunggulan dalam mengingat kata atau paragraf bacaan karena menggunakan kedua sisi otak, maka metode biblioterapi pada remaja perempuan ini lebih efektif dibandingkan oleh remaja laki-laki.

Perbedaan-perbedaan ini disebabkan oleh berbagai faktor meliputi genetik, hormonal, dan lingkungan serta tidak mencerminkan kelebihan (keunggulan) masing-masing untuk kedua jenis kelamin. Hal ini juga diketahui bahwa laki-laki dan perempuan menampilkan kapasitas yang berbeda dalam fungsi kognitif tertentu yang tidak terkait dengan perbedaan dalam tingkat umum kognitifnya. ${ }^{23}$

Menurut hasil penelitian sebelumnya menunjukkan bahwa Biblioterapi dapat membantu anak-anak dan remaja (3 - 18 tahun) dalam penyembuhan dan mengembangkan keterampilan koping yang efektif setelah mereka mengalami trauma. ${ }^{24}$ Metode biblioterapi dapat mengurangi kecemasan akademik siswa. ${ }^{25}$ Berdasarkan hasil penelitian sebelumnya bahwa metode biblioterapi untuk mengatasi trauma dan kecemasan belum ke peningkatan pengetahuan HIV/AIDS dan Program penanggulangan HIV/AIDS belum ditinjau berdasarkan jenis kelamin, maka berdasarkan penelitian ini, disarankan untuk mencari metode yang lebih tepat dan efektif pada remaja laki-laki untuk dapat meningkatkan pengetahuan tentang HIV/AIDS, disesuaikan dengan karakteristik remaja laki-laki.

\section{KESIMPULAN}

Berdasarkan hasil penelitian, peneliti menyimpulkan bahwa metode biblioterapi dapat meningkatkan pengetahuan tentang HIV/AIDS pada remaja perempuan dibandingkan dengan remaja laki-laki di Wilayah Kerja Puskesmas Puger Kabupaten Jember.

\section{SARAN}

Perlu adanya penelitian lebih lanjut untuk mencari metode pembelajaran yang lebih efektif mengenai pengetahuan HIV/AIDS pada kelompok remaja laki-laki.

\section{UCAPAN TERIMA KASIH}

Fakultas keperawatan, Universitas Jember yang telah memberikan ijin penelitian dan responden remaja laki-laki dan remaja perempuan di wilayah kerja puskesmas Puger Kabupaten Jember sebagai lokasi penelitian atas partisipasinya dalam kegiatan penelitian ini.

\section{DAFTAR PUSTAKA}

1. World Health Organization (WHO). Number of people (all ages) living with HIV Estimates by WHO region. (2019).

2. UNAIDS. UNAIDS. (2018).

3. Direktorat Jendral P2P Kementerian Kesehatan Republik Indonesia. Laporan Perkembangan HIV AIDS dan Penyakit Infeksi Menular Seksual (PIMS) Triwulan I. (2019).

4. World Health organization. Global Health Sector Strategy on HIV 2016-2021 towards ending AIDS. World Health Organization. (2016).

5. Kementerian Kesehatan RI. Situasi dan Analisis HIV AIDS. Kementerian Kesehatan RI (2014).

6. Pusat Data dan Informasi Kementerian Kesehatan Republik Indonesia. Situasi umum HIV/AIDS dan tes HIV tahun 20132017. (2017).

7. Dinkes Jember. Profil Kesehatan Kabupaten Jember Tahun 2018. (2018).

8. Komisi Penanggulangan AIDS Daerah. Laporan Kasus HIV/AIDS Tahun 2017. (2017).

9. Nova, C. Iswidhiastuti. Determinan Kesediaan Ibu Hamil Melakukan Konseling dan Tes HIV Atas Inisiasi Petugas Kesehatan (TIPK) di Puskesmas Puger. (2018).

10. Komisi Penanggulangan AIDS Nasional. Rangkuman Eksekutif Upaya Penanggulangan HIV dan AIDS di Indonesia 2006-2011: Laporan 5 Tahun 
Pelaksanaan Peraturan Presiden No. 75/2006 tentang Komisi Penanggulangan AIDS Nasional. (2016).

11. Trihantoro, A., Hidayat, D. R. \& Chanum, I. Pengaruh Teknik Biblioterapi Untuk Mengubah Konsep Diri Siswa. J. Bimbing. Konseling 5, 8-14 (2016).

12. Hidayah, I. Y., Hardiani, R. S. \& Hakam, M. Pengaruh Metode Biblioterapi terhadap Pengetahuan Remaja tentang Hygiene Menstruasi di SMP Negeri 2 Mayang Kabupaten Jember (The Effect of Bibliotherapy Method toward knowledge of Adolescents at SMP Negeri 2 Mayang Jember District). Pustaka Kesehat. 4, 300306 (2016).

13. Hanifah, L. \& Sulistyorini, E. Hubungan Umur dengan Pengetahuan Wanita Usia Subur Tentang Pap Smear. Avicenna J. Heal. Res. 2, 113-120 (2019).

14. George, J. Biblioterapi. (2017).

15. Rohmah, N. Pengaruh Metode Biblioterapi Terhadap Kemampuan Mencuci Tangan Pakai Sabun Pada Siswa Kelas 2 di SDN Banjarsengon 1 Kecamatan Patrang Kabupaten Jember. (2015).

16. Andriansyah, D. \& Rifai, A. Pengaruh Model Pembelajaran Problem Based Instruction ( PBI ) terhadap Pengetahuan dan Sikap Remaja tentang HIV / AIDS di SMP Achmad Jani Puger Kabupaten Jember ( The Effect of Model Learning: Problem Based Instruction ( PBI ) towards Knowledge and Attit. e-Jurnal Pustaka Kesehat. 4, 273-279 (2016).

17. Purwanto, E. Pengaruh bibliotherapy terhadap psychological well-being perempuan lajang Evanthe Purwanto. J. Ilm. Mhs. Univ. Surabaya 4, 1-26 (2015).
18. Sowell ER, Peterson BG, Kan E, et al. Sex differences in cortical thickness mapped in 176 healthy individuals between 7 and 87 years of age. 2017 ; 17: 1550-60. Cereb Cortex 17, 1550-60 (2017).

19. Fauziyah, L. Keefektifan Biblioterapi dalam Meningkatkan Kemandirian Belajar Peserta Didik Kelas X-1PS 2 di MA Sunan Kalijaga Tahun Pelajaran 2012/2014. Univ. PGRI Kediri 6, 10-20 (2015).

20. Bishop KM, W. D. Sex differences in the human corpus callosum: myth or reality? Neurosci Biobehav Rev 21, 58-601 (2017).

21. Chai XJ, J. L. Sex differences in directional cue use in a virtual 112andscape. 2013; 123(2): 276-83. Behav Neurosci 123, 27683 (2013).

22. Phillips MD, Lowe MJ, Lurito JT, Dzemidzic M, M. V. Temporal lobe activation demonstrates sex-based differences during passive listening. 2010; 220(1): 202-7. Radiology 220, 202-7 (2010).

23. Jacklin CN, M. L. Effects of gender on behavior and development. In: Levine $M D$, Carey WB, Crocker AC, Eds. Developmental-behavioral pediatrics. $3 \mathrm{rd}$ ed. 2014; pp. 100-6. Philadelphia, PA: W.B. Saunders (2014).

24. Dawn et al. Healing With Books A Literature Review of Bibliotherapy Used With Children and Youth Who Have Experienced Trauma. 101, 48-74 (2017).

25. Olivia Sriferina, Alizamar, A. \& Marjohan, M. Group Guidance Effectiveness through Bibliotherapy to Reduce Academic Anxiety Journal of Educational and Learning Studies. 2, 88-89 (2019). 